\title{
Preventing Plague in Post-Reformation Aberdeen
}

\author{
Karen Jillings*
}

Between the fourteenth and seventeenth centuries the extensive contacts maintained between Scotland's burghs and their counterparts in England and on the continent entailed the exchange of epidemic diseases, the most terrible and feared of which was plague. The horror of pestilence was familiar to both residents and magistrates of Aberdeen, one of the nation's largest and most influential towns, which by the mid-sixteenth century had experienced two major and several minor visitations of the disease. Thereafter, however, the pattern of infection within the burgh changed markedly. This article discusses Aberdeen's bureaucratic responses to the threat of plague during the subsequent century and contends that the city experienced no renewed outbreak until 1647. This extraordinary gap - unparalleled in any other town was primarily a result of local governmental efforts to utilise the burgh's comparative isolation and dominance of the north-east region in the implementation of effective preventative legislation. ${ }^{i}$

The incidence of past epidemics is one that historians have struggled to explain. Even today there remains debate about modern outbreaks, with regard to both their initial appearance and their eventual disappearance, though the bacillus which causes modern plague was identified at the end of the nineteenth century. The precise bacteriological nature of what early modern commentators described as "plague" remains elusive and a subject of contention, with recent research suggesting that bubonic plague (and therefore the importance of rodents and their fleas as vectors of transmission) played a lesser role than has previously

\footnotetext{
* Karen Jillings is a Lecturer in the School of History, Philosophy and Politics at Massey University in New Zealand.
} 
been assumed.ii Given this, it would be misleading to discuss Aberdeen's prevention of outbreaks in accordance with modern epidemiological understanding. Doing so gives rise to unhelpful theories, such as the notion that the prevailing cold weather might have inhibited the survival of rodent fleas.iii Instead, this article will establish the importance of both isolation and legislation in the city's prevention of plague during the century after 1550 .

Surveys of Scottish medicine have long acknowledged that Aberdeen was "curiously immune" from visitations of pestilence.iv This is apparent not only in a Scottish context, but also in comparison with many of the city's English and European counterparts. Detailed studies of bureaucratic responses to plague have tended to focus on Italian city states, which led the way not only in medical theory and practice but also the care and control of public health. Italian civic responses to plague served as a model for other government bodies, including those in Scotland, to emulate. ${ }^{v}$

The secondary literature on the Scottish experience of plague is limited and case studies are almost non-existent.vi A recent study of Aberdeen before 1800 supports this article's contention that plague epidemics were avoided, and that both comparative isolation and effective civic legislation played a significant role in this:

Aberdeen probably had fewer visitations of the disease than any other large town in the British Isles. There appear to have been ... only three [major epidemics] - in 1514-16, 1547-8 and 1549 - between [1500] and 1550. In 1603, the council register stated that 'it has plesit the gudness of god in his infinit mercie to with hauld the said plaig fra this burght this fifty-five yeris,' despite epidemics nearby. It was not until 1647 that there was a major outbreak. Aberdeen was helped by its distance from other major towns, but the main explanation for the avoidance of the disease was probably the council regulations to prevent the plague from entering the town. .ii $^{-}$

Histories of Aberdeen have emphasised the city's comparative isolation as a result both of topographical features and the 
increasing centralisation of Scotland's political, economic and administrative affairs in the central belt by the sixteenth century. viii In a number of important ways Aberdeen's peripheral location on the north-east coast belied its status as a major centre of commerce, education and diplomacy both at home and abroad. As one of Scotland's largest and most prosperous ports it made one of the highest contributions to nationwide taxation. In Internationally it had consolidated its medieval reputation as one of the "four great towns" of Scotland and it maintained extensive foreign contacts, particularly with its neighbours across the North Sea in the Low Countries and the Baltic. ${ }^{\mathbf{x}}$

Although Aberdeen's size and status ensured its importance in regional, national and international affairs it was nevertheless geographically and topographically isolated, at least within a Scottish context. This had an important bearing on the city's ability to prevent plague. It was sometimes able completely to avoid outbreaks originating in the central belt because they petered out before they reached the area. This had happened on several occasions in the early fifteenth century and it was also the case early in the period under discussion, in 1563-64 and 1574. .i $^{\mathbf{i}}$ When the city did hear of infection in burghs further south it could take months before infection reached the north-east. This timescale generally enabled the authorities to be forewarned of plague's imminence and could therefore implement an effective strategy to counter the arrival of possible carriers.

It was less easy to anticipate the arrival of infection that originated closer to home. Despite this, the surrounding topography of the city generally meant that the task of monitoring the entrance of people and goods into the burgh was relatively straightforward for the local authorities, regardless of whether visitors approached by land or by sea.

The city had been described in the 1460 s as being "beyond the mountains" and, indeed, the barrier of the Mounth hindered easy overland access from the south.xii So too did the inhospitable topography of its immediate environs with marshy ground to the west, a loch (the town's main water supply) to the north-west and the North Sea to the east. There were few decent roads into the city and the river Dee to the immediate south could only be crossed easily by means of a bridge. Moreover this hinterland was 
considerably less populated than those of the other major Scottish towns. Aside from the neighbouring bishop's burgh of Old Aberdeen few settlements in the immediate hinterland numbered more than a couple of hundred souls. It has been noted that this entailed a lower rate of human traffic into the city and hence lessened the chance of infection. ${ }^{x i i}$

The approach by sea was equally restricted. Early modern commentators noted that Aberdeen's only harbour was narrow and difficult to enter, causing some boats to dock instead at the suburban baronial burgh of Torry. xiv This made the arrival of vessels at Aberdeen's port relatively easy to monitor. This task was further helped by the fact that the port was not a busy one by European standards, with an average of perhaps thirty-five vessels departing annually and far fewer during times of recession. ${ }^{\mathbf{x v}}$ Indeed, it has been pointed out that "the limited volume of maritime traffic probably meant that Aberdeen was less prone to the import of deadly diseases than busier ports."xvi

The authorities' plague policy made the most of these factors. From its earliest implementation preventative legislation had been formulated with the advice of learned medical practitioners. This had initially been a formal arrangement, with the council's official employment of the mediciner (professor of Medicine) at King's College in Old Aberdeen. This had been instigated in 1503 with the first incumbent, James Cumming. ${ }^{x v i i}$ After Robert Gray (appointed in 1523) the third physician to become mediciner was local man Gilbert Skene, author of Ane Breve Descriptioun of the Pest, the earliest vernacular medical treatise to be published in Scotland. xviii Having studied under Gray at King's, Skene completed his studies on the continent before returning to take up the post of mediciner at his alma mater in 1556. ${ }^{\text {xix }}$

Despite moving to Edinburgh to become royal physician in 1575 he retained close ties with Aberdeen, as he was made a burgess in 1579 and did not dispose of the mediciner's manse until 1587.xx After Skene's departure the post of mediciner may have remained vacant until the appointment of local man Patrick Dun in 1619. During this time, however, Aberdeen continued to benefit from a learned medical presence within the city. In 1596 the council granted "Master Quintine Preston, professor of phisick" an apothecary's shop and servant, George Peacock who, 
unlike Preston, was made a burgess. ${ }^{x x i}$ Preston possibly taught several students at King's College, including William Gordon, who was made a burgess in 1625 and became mediciner in 1632, after Dun. ${ }^{x i i}$ He owned an apothecary's shop on the Netherkirkgate, which was in competition with the other, run solely by Peacock since Preston's death. ${ }^{\text {xiii }}$

Bureaucratic responses to plague in Aberdeen are detailed in the comprehensive council registers, which record the everyday issues that affected local government. Minutes of the various burgh courts survive extensively, enabling an intricate picture to be reconstructed of social, economic and political life in the town from the end of the fourteenth century. ${ }^{\text {xxiv }}$ "The registers record every piece of legislation passed by the "charmed circle," that exclusive body of influential local men - particularly comprising members of the Menzies family - which made up the ruling council during the entire period. ${ }^{x x v}$ From such informative records it is possible to ascertain precisely when plague threatened and what measures were put in place to address this threat. Magistrates, like their counterparts in every other European town, sought to counter the threat of an outbreak at the earliest opportunity in order to protect the physical well-being of residents, to maintain social order, and to uphold their basic duty of safeguarding the common weal.

Magisterial bodies in Italy and elsewhere appointed specific public health boards to deal with plague. The major cities that did have such institutions were of a sufficient size to enable the creation of governmental sub-committees. A specific health board was never established in Aberdeen simply because the town's size did not require one. In effect the city council was its ad hoc health board. After all, it carried out the same functions - the implementation and supervision of efforts to counter infection - that larger governments had the luxury of contracting out to specific boards. Its ability to perform these functions had been severely tested during the first half of the sixteenth century. The city had been subjected to visitations of plague in 1514-16, 1536, 1545-47 and 1549. The proximity of infection had further necessitated the implementation of preventative legislation in 1498, 1499, 1500, 1506, 1529 and 1530. The authorities developed a set of measures to counter infection that reflected standard governmental efforts to tackle the disease both in Scotland and across Europe. 
Bureaucratic responses to plague had long been formulated in line with a belief held equally by physicians and magistrates, that plague could be spread in two interlinking ways: polluted airborne vapours (miasma) and other forms of contact, though not necessarily direct (contagion). ${ }^{x x v i}$ Regulations to counter each of these were implemented in the event of both the threat and the actuality of plague, and were aimed at targeting any possible source of infection: the promotion of a cleaner environment through the removal of middens and the regulation of "dirty" trades such as tanning and butchering; the restricting of the movements of domesticated animals such as dogs, cats and pigs; the fumigation of the air with sweet-smelling herbs to counter noxious fumes; the patrol of the administrative quarters of the town; the issuing of licences to those wishing to embark on a journey; and the monitoring of visitors to the city through the guarding of official entrances. ${ }^{x x v i i}$

When the city actually became infected the authorities developed a set of measures specifically aimed at tackling the presence of plague within the community. ${ }^{\text {xxviii }}$ In order to limit plague's spread through both miasma and contagion, sufferers were identified and forcibly segregated from general society, often with their entire family. In common with other towns Aberdeen designated an area outside the town boundaries where plague huts were erected to house individuals placed under quarantine. Those fortunate enough to recover were subjected to a stage-by-stage programme through which they were reintroduced to general society. In order that healthy individuals were able to identify and consequently avoid those who had recently emerged from quarantine, former sufferers were distinguished by being made to carry a white stick. In many towns measures were also taken to deal with the practical effects of mass mortality, such as the employment of gravediggers. This was not evidenced in Aberdeen until the final outbreak in 1647, one indication that earlier epidemics experienced by the city were not particularly virulent.

Over the following century measures taken to deal with the practical effects of mass mortality were never implemented. Although legislation was promulgated on numerous occasions to prevent the spread of plague to Aberdeen, this article contends that at no time between 1549 and 1647 did Aberdeen's council implement measures to counter the explicit presence of an 
outbreak within the city. An analysis of the preventative regulations implemented by the authorities reveals that in fact infection never broke out.

By the time plague threatened once again, in 1566, seventeen years had passed since the city's last outbreak. This was within living memory of most residents, and this element of experience should not be underestimated in its ability to mobilise fear of infection and to effect compliance with subsequent plague legislation. For the authorities themselves the chain of experience was equally important: many of those sitting on the council in 1566 had been instrumental in dictating plague policy in earlier years, and it made sense to recall and to build on previous measures.

Initial rumours of "pest and seiknes" to the south (notably Montrose) prompted them to try and prevent the arrival of potential sources of infection. A daytime watch was ordered to prevent anyone coming over the Bridge of Dee, an important overland route into the city from the south. Strangers were not to be received or lodged in the town until it was known they were "clene" and had been licensed to enter. Poor outsiders were expelled and a self-imposed trade embargo was also ordered, with no sea vessels permitted to sail to any southerly place. xxix A fortnight later the regulations were renewed and the outbreak was successfully averted, despite officials accepting bribes from outsiders wishing to enter the city. ${ }^{\mathrm{xxx}}$

The council's measures altered little over the subsequent decades as magistrates fought to prevent the spread of plague from the south. The disease broke out in Edinburgh in 1568, the central belt in 1574 and in Fife (specifically Wester Wemyss, Kirkcaldy and Dysart) ten years later, causing magistrates in Edinburgh and Glasgow to pass preventative legislation and allocate funds to support the sick. ${ }^{x x x i}$ The limiting of contact with potential sources of infection was crucial, so the town was watched and official entrances - including the Bridge of Dee, the harbour and the six gates - were guarded or locked, to prevent unlicensed strangers entering either by "fut or hors." xxxii Back walls and gates were to be secured, so "that na passage [could] be thair by."xxxiii It was important to prevent residents travelling to potentially infected areas, and restrictions were placed on journeying south or to any common fair or market unlicensed. xxxiv 
The following year the government was informed that the disease had broken out in Edinburgh, Perth and Dundee "\& contenewalie Incressis \& spreddis in dyuers partis townes and villagis \& places of the south contraye off this realme." In those burghs it had been deemed necessary to implement remedial measures (which targeted strangers and the poor), to relocate the mint and to construct plague lodges to accommodate sufferers. ${ }^{\mathrm{xxxv}}$ Aberdeen responded to the presence of plague in the south by shutting some of its official entrances and installing a guard at those that remained open in order to prevent the entrance of travellers coming from southern parts. ${ }^{x x x v i}$ This measure was successful as no further mention was made of the threat of plague, despite the disease lingering in the south over the next three years.

After that it disappeared but returned again south of Aberdeen with increased virulence for most of the 1590s. xxxvii Having sought confirmation of plague from magistrates in Brechin (for which the messenger was paid $1 l 10 s$ ), the Aberdeen council, believing the disease to be present in Edinburgh and other parts of Lothian, fought successfully to avoid "all perrell that may...cum be sea to this burght."xxxix There had also been renewed infection in Paisley, which prompted authorities in nearby Glasgow to take preventative action. ${ }^{\mathbf{x}}$ In Dundee the authorities attempted to combat its spread by appointing officials to patrol each quarter and report "gif there be ony sick or diseasit."xli The seventeenth century brought no let up in plague's virulence as it began to encroach on Aberdeen's hinterland, with outbreaks recorded in Kinloss, Fyvie "and sundrie willages thairabout" in 1600.xlii Crail, Glasgow and Edinburgh were infected in 1601-2, supposedly as a result of commercial contact with Copenhagen, prompting Dundee, Stirling and Paisley to prohibit contact with these places. ${ }^{\text {xliii }}$

Despite these outbreaks Aberdeen escaped infection, with magistrates attributing the absence of plague during the fifty-five years before 1603 to divine benevolence. xliv It was also the result of the authorities' effective implementation of preventative legislation. The success of bureaucratic efforts was not because the measures were in some way particularly extraordinary or innovative. Far from it: on each occasion during those fifty-five years that magistrates heard rumours of plague, from either the south or 
abroad, standard legislation was implemented that continued to reflect a belief in the spread of the disease through both contagion and miasma.

It was considered necessary to limit external contact even though this severely disrupted commercial relations. Vessels required a licence to set sail and then could do so only during specified hours. Limitations were placed on importing "geir maist Infective and dangerous," including lime, coals, lint, hemp and fruit, especially "apillis, peris [and] plumbis."xlv Despite the prohibition of boats "or vther weschillis fra the south pairtis" entering the harbour, traders repeatedly flouted those regulations that restricted their business and domestic commerce with Leith, St. Andrews and Dundee continued to take place. ${ }^{x l v i}$

Foreign commerce was also seriously disrupted, though merchants did sometimes continue to trade with continental towns such as Middleburg, Hamburg and Danzig despite the presence of plague. ${ }^{x l v i i}$ Boats that arrived in Aberdeen from places known to be infected were subjected to strict quarantine and cleansing procedures. ${ }^{x l v i i i}$ In the event of the worst-case scenario - confirmation of onboard infection - the ensuing legal wrangle over the fate of the cargo demonstrated the disruption to livelihoods that infection caused.xlix The crew on board a suspect vessel that arrived from Danzig in 1602 were stripped and quarantined, while their clothes and cargo - pitch, tar and iron - were boiled or burned to rid them of infection. It took three weeks before their ordeal came to an end and they were finally judged "clene and frie of the plaig of pestilence." Fines were imposed on the crew and on those who had illicitly visited them during their quarantine. ${ }^{\text {li }}$ The following year Aberdeen merchants travelling to Flanders on board the Johne were allowed to trade only in certain goods, and before docking they were required to secure testimonies at their intended destinations of Campvere and Middleburg that those ports were "frie of all suspitioun of pest."lii

A further threat to civic welfare came from residents themselves, who contravened plague statutes wilfully or otherwise. Several individuals were banished or fined for lodging and feeding outsiders who had entered the town illicitly. This included the "maister of the ewill boit" who had docked at the harbour unlicensed and several individuals who had gained access 
by "clyming the wallis and bak dykis, the ports being fast [closed]." liii A resident from Edinburgh, William Huntar was discovered lodging in the town, even though he had "cum out of suspect places of the pest and speciallie out of dundye." He was quarantined until he had undergone "sufficient trial."liv Four days later Kathrein Huntar (perhaps William's wife) was to be banished if found in the town, as she had visited William and eaten and drunk with him..$^{\text {lv }}$ William was also banished but clearly was still considered a threat, as ten days later both James Conoy and Abarok Bissat were convicted for receiving letters from him. lvi A messenger whom Bissat, also from Edinburgh, had used to correspond with William was fined and banished. ${ }^{\text {vii }}$ It is important to note that these measures were simply a precaution on the part of magistrates and there is no evidence that William was actually infected, or that his presence in the town occasioned an outbreak of plague.

The authorities' measures to prevent plague had thus far made the most of the city's particular circumstances of the city. From the earliest implementation of plague regulations in Aberdeen the burgh's topographical isolation had enabled official entrances to be guarded in order to monitor the approach of outsiders. The one aspect that undermined this favourable situation was the lack of an encircling outer wall. The absence of this forced magistrates to rely on the goodwill of those residents living on the outskirts of town whose own back walls and gates effectively formed the outer boundaries of the city. It had become apparent that this goodwill could not be relied upon. During the outbreaks of the 1540s the council had dispensed with its earlier policy of attempting to prevent the initial entrance of infection by securing back walls and gates, as this had proved impossible to enforce. Initial post-Reformation measures heralded a return to regulations that had been implemented when plague had first threatened at the beginning of the sixteenth century. ${ }^{\text {lviii }}$

While it proved difficult to prevent potentially infected outsiders from entering the town, other aspects of the authorities' efforts to ward off plague were more encouraging. By improving networks of communication the council became better informed as to the whereabouts of infection and consequently adjusted its plague policy to target specific sources of infection effectively. 
The city dominated the largest rural hinterland of any Scottish town, which entailed a "more complex interaction of town and country" than for any other. ${ }^{\text {lix }}$ Magistrates were able to discern where infection was located and to adjust their targeting of visitors coming from certain places of origin accordingly. By 1600 , for example, it was clear that the presence of infection in Moray and Speyside necessitated the targeting of people arriving over land, rather than from the south or by sea. ${ }^{\mathrm{x}}$ The authorities were subsequently able to acknowledge that burghs elsewhere were obeying ordinances for "watching and keeping" their towns, and consequently could order the same to be done in Aberdeen. 1xi They also returned the favour, such as in 1601 when they sent letters to local governments in Newburgh, Peterhead and Fraserburgh, instructing them not to "suffir the boit [from Edinburgh] suspect of the pest to entir in thair herbeoris."'xii

The relatively small population of the region enabled Aberdeen to maintain close communications with other towns and settlements, the extent of which widened considerably over time. We must be mindful that this interpretation is inevitably due in part to the survival of letters sent by the council that do not exist for the earlier half of the sixteenth century. Bearing this in mind, the council registers demonstrate that there was a more efficient network of communication being extended to other towns and villages, through which rumours of impending plague might be confirmed and advice passed on about appropriate responses. By the early seventeenth century this was being carried out within days; in 1514 it had been a whole year before magistrates became aware of an outbreak in Edinburgh.

It is obvious from the number of individual infected places mentioned in legislation (and those with which communication was being maintained) that the authorities were becoming far better informed about where exactly plague had broken out. By bettering communications with towns further along both the Dee and the Don Rivers, as well as further north and west of the city, magistrates increased their cordon sanitaire. This helped the council, by the later part of the period, to pinpoint epidemics and subsequently avoid them with greater success.

The maintenance of efficient communication networks was important in ensuring Aberdeen's continuing avoidance of plague 
into the seventeenth century. The absence of infection was a favourable situation, of course, but it had its disadvantages. With no actual outbreaks with which to contend the element of personal experience that might ensure fear of plague among both residents and magistrates dwindled away to nothing. This seriously concerned the authorities, who came to believe that because the town had been spared an outbreak for fifty-five years residents were beginning to regard plague statutes with "ane sluggische cairlesnes" and had "littill fear" in disobeying them. Ixiii To counter their fear of complacency magistrates petitioned the Privy Council for a Commission to enforce the punishment (whether death or imprisonment) of those who contravened plague regulations. ${ }^{\text {Ixiv }}$

The decision to send a Commission was officially approved by the Privy Council the following month, along with permission for local officials to impose such punishments until the Commission arrived. ${ }^{\mathbf{x v}}$ Six or seven persons in each administrative quarter of the city were chosen to assist the authorities in the task. ${ }^{\text {xvi }}$ A watch was also installed at the harbour so that no sea vessels could land unlicensed, and instructions for taking similar action were sent to Peterhead and Fraserburgh. Ixvii Letters were also sent by the town to the nearby burghs of Monymusk, Pitfoddels, Drum and Kincardine, ordering them to install watches and "receive no one coming from the Forth, for feir of the pest."Ixviii

The Commission that had been requested in October 1603 arrived from Edinburgh by the following May. The authorities were keen to prevent "all suspect and foull persones" from the south being allowed into Aberdeen, which was "as yit clene fra the said seiknes." "xix The Commission reiterated its permission for the council to do whatever was necessary in order to ensure the city remained plague-free. Any infected persons arriving in the town were to be put to death and anyone entering the town illicitly, either "over the wallis, or vthervayis by the commoun portis," was also to be punished.

The Commission's intervention was timely, for plague had broken out across the central belt and was understood to be spreading north into "sum partis of Fyff and Angous." lxx The Aberdeen council's ordinances were renewed, especially the 
installation of a watch, the securing of back walls and gates and the prohibition of lodging strangers. ${ }^{\text {.xxi }}$ Magistrates considered postponing nearby summer markets in case infection spread, and a messenger rode to Newburgh "to conuene with the barrons on Ythane syde" about guarding the river Ythan "in tyme of pest." Action was also taken to prevent the entry of infection into Slains, Cruden and Foveran, and one resident was fined $40 l$ for travelling south without a licence. ${ }^{\text {Ixxii }}$

During subsequent decades plague continued to threaten both from the south and the continent, prompting the renewal of standard preventative measures. ${ }^{\text {lxxii }}$ The number and location of the Aberdeen authorities' informants continued to grow as they sought to ensure they were aware of every instance of nearby plague. The incidence of infection in 1606 indicates the effectiveness of this. Attempts by magistrates in Dundee that summer to prevent infection spreading from the central belt were hindered by the non-compliance of certain residents, one of whom attended market in Elgin, in spite of "the grite infection there." Another was found guilty of lodging a resident of Edinburgh. lxxiv Perhaps not surprisingly plague broke out within Dundee itself soon afterwards, resulting in a virulent epidemic that lasted for two years during which "thair departit 4000 personis." $1 \mathrm{xxv}$

The outbreak was rumoured to have spread north and the Aberdeen authorities sent for news of plague from many nearby towns, including Fyvie, Fetteresso, Whitehaugh, Strathaquin, Newburgh, Banff, Lumphanan, Hillhead and Kincardine. ${ }^{1 x x v i}$ Having received the news they had feared - that "dyvers partis of Dee syid, and vtheris partis heirabout" - were infected, the authorities imposed restrictions on commercial relations, particularly with Old Rayne and Turriff.lxxvii These were lifted once the infection in the hinterlands had been "quenchit," at least until such time as magistrates "ressaue new adverteisment of new infectioun."|xxviii In the event plague lingered for another couple of years throughout the central belt and Fife. It also spread throughout Aberdeenshire, including to Peterhead. ${ }^{1 x x i x}$

It is absolutely remarkable just how close infection came to Aberdeen, as a resident in Torry was ordered not to enter the city "for fear he had the pest" in 1605 and the following year the disease reached Old Aberdeen. ${ }^{1 \times x x}$ Plague subsequently broke out 
in Torry in 1608, whereupon Walter Findlayson was employed to cleanse that burgh and burn dead bodies. Ixxxi Despite the disease being in such close proximity magistrates in Aberdeen registered no alarm beyond ordering that gibbets be erected in the Futty quarter of the city to deter residents from having contact with anyone in neighbouring Torry. 1 xxxii

A recent study of health care in Aberdeen claims that plague did break out within the city in 1608 but offers neither evidence nor reasoning to substantiate this. ${ }^{\text {xxxiii }}$ Shortly afterward plague reached Stonehaven, Belhelvie and Cowie, and the accounts of the dean of guild recorded various expenses occasioned by efforts to tackle plague within those localities. Infection in each necessitated the fumigation of a property (for which the owner received compensation), the employment of cleansers and the implementation of quarantine procedures. Ixxxiv If plague had broken out within Aberdeen in 1608 it seems odd that the guild accounts do not record any expenses for similar efforts to target its presence within the city. Likewise, the council registers mention neither the actual presence of the disease nor explicit attempts, such as the implementation of quarantine procedures, to tackle it. Instead, it is more likely that on this occasion Aberdeen itself escaped infection.

Over the subsequent twenty years plague again broke out in Edinburgh and further south, and was also rumoured variously to be present in Kintore, Inverurie, Alford and even Orkney. ${ }^{\operatorname{xxxv}}$ Plague also threatened from England and the continent, prompting the monitoring of the harbour and the prohibition of commercial contact with London, Amsterdam, Leiden, Zeeland and Flanders. ${ }^{\text {xxxvi }}$ The Aberdeen authorities felt it necessary to warn the ports of Peterhead and Newburgh of the danger of infection. Ixxxvii Throughout this entire time the city continued to avoid plague.

Despite extensive intermittent outbreaks elsewhere, the most remarkable aspect of Aberdeen's experience of plague is the city's prevention of infection during the century after 1549. After all, it was certainly not the case that the incidence of plague fell throughout the rest of Scotland. Indeed, the absence of the disease within the burgh is particularly remarkable given the extent to which areas to the north, west and south of the city were affected 
in the century after 1550. Plague threatened Aberdeen numerous times during this period but the council registers, which are otherwise comprehensive, provide no indication whatsoever of its presence within the town itself. The pattern of previous response and the bureaucratic concern for the safeguarding of the common weal make it highly improbable that plague broke out within the city but that magistrates took no action. Given the importance of bureaucratic "memory" it is also very unlikely to have been the case that they responded to an outbreak but did not record what measures they took. Even if this were the case surely the effects of plague would in some other way have been evidenced (even indirectly) in the council registers or the accounts of the dean of guild.

A number of further points indicate that Aberdeen completely escaped plague during this period. The first is that when the disease had broken out during the first half of the sixteenth century the council minutes had explicitly referred to the presence of infection and its victims, reflecting a sense of immediacy and urgency in the legislation. ${ }^{\text {xxxviii }}$ But at no time was this the case in the records for 1550-1647. Moreover, during both these earlier outbreaks and that which occurred in 1647 magistrates' efforts were specifically aimed at countering the presence of infection. ${ }^{\text {lxxxix }}$ These particular measures included: the erection of plague huts to accommodate those infected or suspected of infection; the identification, segregation and quarantining of suspected victims and their families, and their subsequent reintroduction into healthy society; and the employment of personnel to perform certain necessary tasks occasioned by large-scale infection and death, including grave diggers, visiting physicians, searchers and cleansers. Although during the period 1550 and 1647 individuals occasionally had their goods cleansed or were themselves put under quarantine, this was simply a precaution. None of the other measures was implemented in Aberdeen and it ought to be concluded that the city escaped infection during this period.

How was the city able to do this? The answer lies in the success of bureaucratic action on each known occasion when plague threatened Aberdeen. It was not the case that regulations were successful because they were particularly innovative or unique. Indeed, quite the reverse was true. When the disease 
first threatened the post-Reformation burgh in 1566, less than twenty years had elapsed since the city's last outbreak. On both this and subsequent occasions magistrates "revised and refined the procedures, consulting old men and old records to make sure they had missed nothing."xc For magistrates, the best defence continued to be experience. As plague was a relatively recent affliction the rational response was to recall previously implemented legislation. ${ }^{x c i}$

So there was nothing new or unique about any of the measures implemented by Aberdeen. How, then, did these measures meet with more success than those implemented in Edinburgh and other burghs? The issue of compliance might be one factor, for the implementation of legislation counted for little if it could not be enforced. An early study of plague in the British Isles noted that "there can be no question of the draconian rigour of [Aberdeen's] decrees against the plague" during the post-

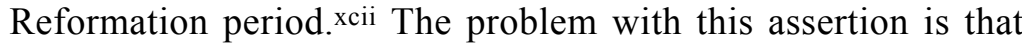
there is no evidence that Aberdeen's legislation was any more severe than that of its counterparts, in Scotland at least. There is general agreement that burghs throughout Scotland enforced their plague policy with more severity than authorities elsewhere, including England. ${ }^{x c i i i}$

But this was only apparent with regard to the punishments that were threatened. A recent analysis has concluded that Aberdeen's punishments were "severe."xciv Magistrates erected gibbets in 1585 at the market cross, the Bridge of Dee and the harbour mouth to act as a deterrent to the contravention of plague statutes. There is, however, no explicit evidence that they were ever used. Indeed, despite their presence a number of individuals were subsequently punished for breaking plague statutes only by being banished or fined. ${ }^{\mathrm{xcv}}$ Nevertheless magistrates in Aberdeen presumably considered them a sufficient deterrent to contravention, for they were subsequently re-erected in 1608 (when plague was in nearby Torry). ${ }^{\text {xcvi }}$ Gibbets were also erected as a deterrent in Edinburgh and do not appear to have been used. ${ }^{x c v i i}$ So far as punishment is concerned, where Aberdeen's council differed from its counterparts was perhaps in its determination to ensure compliance through the appointment of a Commission in 1603 to enforce the punishment of individuals who contravened plague 
statutes. That the Commission was not apparently called on to do its job might reflect the fact that its very presence was a deterrent to contravention.

It seems more likely that Aberdeen's legislation was successful because of the town's comparative isolation and surrounding topography. Each of these factors was rather unique to the city and enabled magistrates to implement their preventative plague policy to a greater degree than was possible elsewhere. Contemporaries understood the absolute necessity of ensuring that infection remained as far away as possible. Throughout Europe governments attempted to prevent plague from penetrating their local environment by implementing measures designed to ensure that potential sources of infection could not arise from within or enter from outside. People, animals and goods could each harbour disease and magistrates strived to keep out all known or suspected sources of infection.

Aberdeen was better placed to achieve this because it was comparatively isolated from burghs further south, which were hit by plague on numerous occasions during the period. It was therefore able to avoid some outbreaks altogether (such as that of 1563-64). Its isolation did not, however, prevent infection spreading throughout the north-east. When the proximity of disease threatened Aberdeen the city was helped by the surrounding topography, which meant that visitors to the town could be monitored and controlled to a greater extent than elsewhere. The establishment of extensive networks of communication was crucial in enabling authorities in Aberdeen to identify nearby outbreaks and prevent the arrival, whether by sea or by land, of everyone and everything from a targeted area. The city's ability to escape infection during the century after 1550 was a feat unmatched by any other town in the British Isles. Aberdeen's significant achievement in preventing plague ought to be situated in its wider context, and should serve as a lesson to medical and social historians not to ignore the Scottish experience in analysing broader European trends. 


\section{NOTES}

i The English city of York escaped plague for almost fifty years from 1559, but no other major urban community seems to have bettered this. See D.M. Palliser, 'Epidemics in Tudor York', Northern History 8 (1973), 45-63.

ii S. Scott and C. Duncan, Return of the Black Death: The World's Greatest Serial Killer (London, 2004) and Biology of Plagues: Evidence from Historical Populations (Cambridge, 2001); S. Cohn, The Black Death Transformed: Disease and Culture in Early Renaissance Europe (Oxford, 2002); G. Twigg, The Black Death: A Biological Reappraisal (New York, 1985).

iii A view expressed by J.F.D. Shrewsbury, A History of Bubonic Plague in the British Isles (Cambridge, 1970), which was refuted by A.B. Fitch, 'Assumptions about Plague in Late Medieval Scotland', Scotia 11 (1987), 30-40 (33).

iv J.D. Comrie, History of Scottish Medicine (London, 1932), i, 217; H. Dingwall, A History of Scottish Medicine (Edinburgh, 2003); D. Hamilton, The Healers: A History of Medicine in Scotland (Edinburgh, 1981).

v See, for example, C. Cipolla, Cristofano and the Plague: A Study in the History of Public Health in the Age of Galileo (London, 1973); J. Henderson, 'Epidemics in Renaissance Florence: Medical Theory and Government Response', in N. Bulst and R. Delort (eds.), Maladie et Société (XIIe-XVIIIe Siècles) (Paris, 1989), 165-186; and the following works by Ann Carmichael: Epidemic Diseases in Early Renaissance Florence (Ann Arbor, 1980); 'Plague Legislation in the Italian Renaissance', Bulletin of the History of Medicine 57 (1983), 508-525; Plague and the Poor in Renaissance Florence (Cambridge, 1986); 'Contagion Theory and Contagion Practice in Fifteenth-Century Milan', Renaissance Quarterly 44 (1991), 213-256; 'Epidemics and State Medicine in Fifteenth-Century Milan', in R. French (ed.), Medicine from the Black Death to the French Disease (London, 1998), 221-247.

vi Aside from the works by Comrie, Dingwall, Fitch, Hamilton and Shrewsbury already cited, see also T.C. Smout, 'Coping with Plague in Sixteenth and Seventeenth Century Scotland', Scotia 2 (1978), 19-33; C.F. Mullett, 'Plague Policy in 
Scotland, 16th - 17th Centuries', Osiris 9 (1950), 435-456; W.J. MacLennan, 'The Eleven Plagues of Edinburgh', Proceedings of the Royal College of Physicians of Edinburgh 31 (2001), 256261; J.M. Wood, 'Some Account of the Plague in Edinburgh in Olden Days', Caledonian Medical Journal 11 (1918), 40-46; C. Creighton, A History of Epidemics in Britain (Cambridge, 1891).

vii R.E. Tyson, 'People in the Two Towns', in E.P. Dennison, D. Ditchburn and M. Lynch (eds.), Aberdeen Before 1800: A New History (East Linton, 2002), 111-128 (113). The council entry regarding 1603 comes from Aberdeen Council Registers [ACR], 41.408 [11 Oct. 1603].

viii Dennison, Ditchburn and Lynch (eds.), 'Preface', in Dennison, Ditchburn and Lynch (eds.), Aberdeen Before 1800; J.S. Smith (ed.), New Light on Medieval Aberdeen (Aberdeen, 1985); A. Keith, A Thousand Years of Aberdeen (Aberdeen, 1972); J. Robertson, The Book of Bon-Accord: A Guide to the City of Aberdeen (Aberdeen, 1839); W. Thom, The History of Aberdeen, Containing an Account of the Rise, Progress and Extension of the City from a Remote Period to the Present Day, 2 vols. (Aberdeen, 1811); R. Wilson, An Historical Account and Delineation of Aberdeen (Aberdeen, 1822); W. Kennedy, Annals of Aberdeen, from the Reign of King William the Lion, to the End of the Year 1818, 2 vols. (London, 1818).

ix The town almost doubled in size in the period after 1550 , to 8,300 residents just before the final plague outbreak. Only Edinburgh, Glasgow and Dundee had greater populations. See Tyson, 'People in the Two Towns', 112. Aberdeen regularly made the third highest contribution after Edinburgh and Dundee. See J.D. Marwick (ed.), Extracts from the Records of the Burgh of Edinburgh, 1528-1557 [Edinburgh Extracts II] (Edinburgh, 1871), 117 [2 Oct. 1545] 149 [25 Aug. 1550]. Scotland's third university had been founded in the neighbouring bishop's burgh of Old Aberdeen in 1495; New Aberdeen got its own in 1593 with the foundation of a college by the fourth Earl Marischal.

$x$ A mid-fourteenth century proclamation from Bruges also recognised Perth, Dundee and Edinburgh as "great towns." See M. Verschuur, 'Merchants and Craftsmen in Sixteenth-Century Perth', in M. Lynch (ed.), The Early Modern Town in Scotland (London, 1987), 36-54 (37). 
xi Aberdeen avoided plague in the early 1400s and again in the 1430s. See W.C. Dickinson (ed.), Early Records of the Burgh of Aberdeen, 1317, 1398-1407 (Edinburgh, 1957), 8, 211; Comrie, History of Scottish Medicine, 203; J. Ritchie, 'A Plague 'Testimonial' of the Sixteenth Century', Caledonian Medical Journal 15, n.s. (1932), 94-98; R. Adam (ed.), Edinburgh Records: the Burgh Accounts (Edinburgh, 1899), i, 455; J.D. Marwick (ed.), Extracts from the Records of the Burgh of Edinburgh, 1557-1571 [Edinburgh Extracts III] (Edinburgh, 1875), 182 [11 Aug. 1564], 184 [25 Aug. 1564].

xii Dennison, Ditchburn and Lynch, 'Preface', in Dennison, Ditchburn and Lynch (eds.), Aberdeen Before 1800, xxv. The Mounth was the term used for the spine of the Grampians.

xiii Peterhead and Fraserburgh were the only other "true towns" in Aberdeenshire, while ancient royal burghs such as Inverurie and Kintore had populations of only around 300. See I. Blanchard, E. Gemmill, N. Mayhew and I.D. Whyte, 'The Economy: Town and Country', in Dennison, Ditchburn and Lynch (eds.), Aberdeen Before 1800, 129-158 (150).

xiv This was commented on by Jean de Beaugue, who came to Scotland as part of a French military force in 1548 and James Gordon of Rothiemay, who in the 1660s wrote a detailed account of Aberdeen. See P.H. Brown (ed.), Early Travellers in Scotland (Edinburgh, 1891), 66; J. Gordon, A Description of Bothe Touns of Aberdeene (Edinburgh, 1842), 18.

xv D. Ditchburn and M. Harper, 'Aberdeen and the Outside World', in Dennison, Ditchburn and Lynch (eds.), Aberdeen Before 1800, 377-407 (379).

xvi Ditchburn and Harper, 'Aberdeen and the Outside World', 380.

xvii ACR, 8.278 [20 Oct. 1503].

xviii R. French, 'Medical Teaching in Aberdeen: from the Foundation of the University to the Middle of the Seventeenth Century', History of Universities 3 (1983), 127-157 (132-133); G. Skene, Ane Breve Descriptioun of the Pest, Quhair in the Causis, Signis and Sum Speciall Preseruatioun and Cure Thairof ar Contenit, in W.F. Skene (ed.), Tracts by Dr. Gilbert Skeyne, Medicinar to his Majesty (Edinburgh, 1860). 
xix French, 'Medical Teaching in Aberdeen', 136; A. Keller, 'The Physical Nature of Man: Science, Nature, Mathematics', in J. MacQueen (ed.), Humanism in Renaissance Scotland (Edinburgh, 1990), 97-122 (103).

xx A.M. Munro (ed.), 'Register of the Burgesses of Guild and Trade in the Burgh of Aberdeen, 1399-1631', in Miscellany of the New Spalding Club 1 (Aberdeen, 1890), 74.

xxi ACR, 36.598 [2 Sept. 1596]; 'Register of Burgesses', 89.

xxii 'Register of Burgesses', 139.

xxiii French, 'Medical Teaching in Aberdeen', 153. The fate of the mediciner's post after Gordon's death (c.1640) is obscure.

xxiv This is one of the best preserved collections in any European archive, surviving from 1398 with only one lacuna (1413-33). See I. Flett and J. Cripps, 'Documentary Sources', in M. Lynch, M. Spearman and G. Stell (eds.), The Scottish Medieval Town (Edinburgh, 1988), 18-41 (25). A discussion of plague in Edinburgh has commented that the council registers for that city are of particular value because of their immediacy: "they provide information on the thoughts and decisions taken before an event, and modification of these with further developments." See MacLennan, 'Eleven Plagues of Edinburgh', 256.

$x x v$ A. White, 'The Impact of the Reformation on a Burgh Community: The Case of Aberdeen', in Early Modern Town, 81-101 (82); A. White, 'The Menzies Era: Sixteenth-century Politics', in Dennison, Ditchburn and Lynch (eds.), Aberdeen Before 1800, 224-237.

xxvi Aside from touch, physicians also wrote of the ability to catch plague through sight of the victim alone. See Henderson, 'Epidemics in Renaissance Florence', 171.

xxvii The six official entrances to the burgh were the Gallowgate, Upperkirkgate, Netherkirkgate, Shiprow, Justice and Futty ports. See E.P. Dennison, A.T. Simpson and G.G. Simpson, 'The Growth of Two Towns', in Dennison, Ditchburn and Lynch (eds.), Aberdeen Before 1800, 13-43 (20).

xxviii ACR, 9.336 [24 Apr. 1514] - ACR, 9.584 [5 May 1516]; ACR, 18.527 [25 Sept. 1545] -ACR, 19.394 [19 Sept. 1547]; ACR, 20.310 [16 Oct. 1549] - ACR, 20.318 [8 Nov. 1549].

xxix ACR, 26.209 [2 Sept. 1566]. This treatment of the poor 
was repeated when plague later threatened. See ACR, 31.490 [28 Sept. 1584]. Later regulations ordered the expulsion of all idle beggars regardless of local ties. See ACR, 40.413-414 [10 Feb. 1602]; ACR, 41.672-673 [8 May 1604].

xxx ACR, 26.226 [23 Sept. 1566].

xxxi Edinburgh Extracts III, 253-256 [13 Oct. 1568; 15 Oct. 1568; 10 Nov. 1568]; J.D. Marwick, (ed.), Extracts from the Records of the Burgh of Edinburgh, 1573-1589 [Edinburgh Extracts IV] (Edinburgh, 1882), 28-31 [15 Oct. 1574 - 18 Feb. 1575] and 344-358 [22 July 1584 - 26 Oct. 1584]; J.D. Marwick (ed.), Extracts from the Records of the Burgh of Glasgow, 15731642 [Glasgow Extracts] (Glasgow, 1876), 27-30 [29 Oct. 1574] and 110-112 [28 Sept. 1584; 29 Sept. 1584]; L. MacBean, The Kirkcaldy Burgh Records (Kirkcaldy, 1908), 89-106.

xxxii ACR, 26.637 [2 Oct. 1568].

xxxiii ACR, 31.488 [28 Sept. 1584].

xxxiv ACR, 31.489 [28 Sept. 1584].

xxxv Edinburgh Extracts IV, 413-447 [30 Apr. 1585 - 19 Jan. 1586] and 462-463, 505-507 [10 June 1586; 22 June 1586; 3 Nov. 1587 - 17 Nov. 1587]; D. Peacock, Perth: Its Annals and its Archives (Perth, 1849), 478-480; A. Maxwell, The History of Old Dundee (Edinburgh, 1884), 262-263.

xxxvi ACR, 31.612-613 [21 May 1585].

xxxvii Plague was present in Edinburgh for most of the decade, compelling the authorities to instigate myriad measures to combat its spread. See M. Wood and R.K. Hannay (eds.), Extracts from the Records of the Burgh of Edinburgh, 1589-1603 [Edinburgh Extracts V] (Edinburgh, 1927), 27-209 [16 Oct. 1590 - 4 Jan. 1598]. It had also reached Kirkcaldy by October 1597, forcing the authorities to appoint additional officers to address the crisis. See MacBean, Kirkcaldy Records, 149-150.

xxxviii The messenger, Michaell Fergus, had been instructed to deliver a letter to the baillies of Brechin "anent the plaig." See 'Accounts of the Dean of Guild', 64 [18 Aug. 1597].

xxxix ACR, 36.754 [7 Sept. 1597].

xl Glasgow Extracts, 117-120 [9 Oct. 1585; 23 Oct. 1588-31 Oct. 1588], passim. No records between April 1586 and October 
1588 survive, nor do any for Paisley during this period.

xli Maxwell, History of Dundee, 371.

xlii ACR, 39.690 [5 Nov. 1600].

xliii Edinburgh Extracts $V$, 294-308 [30 Oct. 1601 - 11 June 1602]; R. Renwick (ed.), Extracts from the Records of the Royal Burgh of Stirling, 1519-1666 [Stirling Extracts] (Glasgow, 1887), 100 [18 Dec. 1601; 21 Dec. 1601]; W.M. Metcalfe (ed.), Charters and Documents Relating to the Burgh of Paisley (1163-1665) and Extracts from the Records of the Town Council (1594-1620) [Paisley Extracts] (Paisley, 1902), 248-249 [28 Jan. 1602]; Maxwell, History of Dundee, 372.

xliv The "infinit mercie" of God. See ACR, 41.408 [11 Oct. 1603].

xlv ACR, 31.489 [28 Sept. 1584]; ACR, 41.356-358 [13 Sept. 1603].

xlvi ACR, 27.003 [18 Feb. 1569]; ACR, 27.054 [27 May 1569]; ACR, 27.083 [30 June 1569]; S. Mowat, The Port of Leith: Its History and its People (Edinburgh, 1993), 131; ACR, 31.498 [8 Oct. 1584]; ACR, 36.754 [7 Sept. 1597]. While Aberdeen's port could be monitored fairly easily it was apparent that some traders slipped through the net.

xlvii ACR, 26.650 [20 Oct. 1568]; ACR, 26.661 [5 Nov. 1568]; ACR, 27.141 [19 Sept. 1569]; ACR, 26.083 [30 June 1569].

xlviii ACR, 27.154 [7 Oct. 1569]; ACR, 40.739 [23 Aug. 1602]; ACR, 40.767 [8 Sept. 1602]. The danger posed by vessels from Danzig at this time was also recognised by the Edinburgh authorities. See Edinburgh Extracts V, 310 [11 Aug. 1602]; 318 [18 Mar. 1603].

xlix It was confirmed that one of the crew aboard the "schip of montroiss" arriving in Aberdeen had "deit of the plaig" on leaving Danzig. See ACR, 40.809 [27 Sept. 1602]; 'Accounts of the Dean of Guild', 74.

1 ACR, 40.811-817 [28 Sept. 1602]; ACR, 40.833 [13 Oct. 1602].

li ACR, 40.842-843 [20 Oct. 1602].

lii ACR, 41.356-358 [13 Sept. 1603]. The Johne, with the same captain, was still travelling between Aberdeen and Flanders 
six years later. See L.B. Taylor (ed.), Aberdeen Borough Shore Work Accounts, 1596-1670 (Aberdeen, 1972), 57 [9 Nov. 1609].

liii ACR, 31.616 [27 May 1585]; ACR, 31.662 [23 Aug. 1585]; ACR, 40.305 [2 Dec. 1601].

liv ACR, 31.666 [4 Sept. 1585].

lv ACR, 31.666 [8 Sept. 1585].

lvi ACR, 31.667 [8 Sept. 1585]; ACR, 31.668 [18 Sept. 1585].

lvii ACR, 31.668 [20 Sept. 1585].

lviii ACR, 7.934-35 [19 May 1498]; ACR, 8.562 [8 June 1506]; ACR, 8.594 [10 July 1506]

lix Dennison, Ditchburn and Lynch, 'Preface', xxv.

lx ACR, 39.690 [5 Nov. 1600].

lxi ACR, 40.415 [10 Feb. 1602].

lxii ACR, 40.305 [2 Dec. 1601].

lxiii ACR, 41.408 [11 Oct. 1603].

lxiv Duncan Donaldsonne, the messenger instructed to travel to Edinburgh to make the request, was paid $9 l 6 s \quad 8 d$ for carrying out his duties. See 'Accounts of the Dean of Guild', 74.

1xv L.B. Taylor (ed.), Aberdeen Council Letters, vol. 1: 15521633 (Oxford, 1942), 94-95 [4 Nov. 1603]. A messenger later received $10 \mathrm{~s}$ for bringing home the letters of authorisation. See 'Accounts of the Dean of Guild', 74.

lxvi ACR, 41.437-438 [26 Oct. 1603]. Permissible measures against the spread of plague included: the separation of "foull and suspectit persouns from the clein"; the prevention of anyone leaving the burgh without a licence; the creation of new official posts to ease the task; and the taxation of inhabitants for financing preventative regulations and "for nurisheing and interteining of the puir misterfull people" if any became infected. See Taylor (ed.), Aberdeen Council Letters, vol. 1, 94-95 [4 Nov. 1603]. These reflected measures implemented against the presence of plague in Edinburgh and authorities in Aberdeen found they did not need to employ either the first or last measure.

lxvii ACR, 41.408 [11 Oct. 1603]; 'Accounts of the Dean of Guild', 74 (the messenger received 10s).

lxviii Renewed instructions were also sent to the ports of 
Newburgh, Boddam, Colliston, Peterhead, Fraserburgh and Banff. See 'Accounts of the Dean of Guild', 75.

lxix This was rather ironic, as plague had recently broken out again in Edinburgh and members of the Commission had themselves travelled to Aberdeen from an infected place. See M. Wood (ed.), Extracts from the Records of the Burgh of Edinburgh, 16041626 [Edinburgh Extracts VI] (Edinburgh, 1931), 3-11 [11 Apr. 1604-20 Mar. 1605].

1xx Stirling Extracts, 110-111 [2 May 1604; 1 June 1604; 4 June 1604; 16 July 1604]; Paisley Extracts, 264, 268 [11 Aug. 1604; 11 Oct. 1604].

lxxi ACR, 41.715 [4 June 1604].

lxxii 'Accounts of the Dean of Guild', 75-76.

lxxiii ACR, 42.314-315 [14 Aug. 1605]. The Dundee authorities also banished several residents who had brought infected goods from St. Andrews into the burgh. A ship "being suspect of plague" was ordered to be taken further up the river. See Maxwell, History of Dundee, 372-373. The Stirling council believed infection to be in "sindrie pairtes of Fyff," while authorities in Glasgow took precautions against an outbreak spreading throughout Leith, Linlithgow and Edinburgh. See Stirling Extracts, 113 [3 May 1605]; Glasgow Extracts, 229, 231-232 [27 July 1605; 10 Aug. 1605; 31 Aug. 1605]; Edinburgh Extracts VI, 14 [28 Aug. 1605]; J. Stuart (ed.), 'The Treasurer's Accounts', in Miscellany of the Spalding Club 5 (Aberdeen, 1852), 151.

lxxiv Maxwell, History of Dundee, 373-374; Glasgow Extracts, 248, 251-253 [28 June 1606; 20 Aug. 1606; 21 Aug. 1606; 20 Sept. 1606]; Edinburgh Extracts VI, 24 [1 Oct. 1606].

lxxv Maxwell, History of Dundee, 374-380; E.P.D. Torrie, 'Medieval Dundee: a Town and its People', Abertay Historical Society Publications 30 (1990), 104-105.

lxxvi 'Accounts of the Dean of Guild', 79.

lxxvii ACR, 42.849 [19 July 1606]. The parson of the latter parish requested confirmation of plague in Dalgety in Fife. See 'Accounts of the Dean of Guild', 77-79. lxxviii ACR, 42.1080 [26 Dec. 1606]. lxxix ACR, 43.073 [22 Apr. 1607]; 'Accounts of the Dean of 
Guild', 82; ACR, 43.071 [20 Apr. 1607]; Stirling Extracts, 114115, 117-118 [16 Oct. 1606; 30 Jan. 1607; 9 Feb. 1607; 14 Feb. 1607; 1 May 1607]; Peacock, Perth, 480-481.

Ixxx 'Accounts of the Dean of Guild', 78; A.M. Munro (ed.), Records of Old Aberdeen, 1157-1891, vol. 1 (Aberdeen, 1899), 39-40 [3 Mar. 1606; 11 July 1606].

1xxxi ACR, 43.765-766 [8 Nov. 1608]; ACR, 43.903-907 [22 Mar. 1609]; 'Accounts of the Dean of Guild', 93; Stuart (ed.), 'Treasurer's Accounts', 140. The epidemic had spread from Perth, Burntisland and "uther pairtes be northe [of] the watter of For the," according to the Stirling authorities. See Stirling Extracts, 120-121 [3 Sept. 1608]. Magistrates in Glasgow were also aware of the imminent danger of infection from this area. See Glasgow Extracts, 288, 294-295 [5 Sept. 1608; 29 Oct. 1608].

lxxxii Gilbert Main took his boat to Torry from Futty, perhaps resulting in it being cleansed, as he was subsequently paid $4 l$ to have it mended. See 'Accounts of the Dean of Guild', 84-85.

lxxxiii E.P. Dennison, G. DesBrisay and H.L. Diack, 'Health in the Two Towns', in Dennison, Ditchburn and Lynch (eds.), Aberdeen Before 1800, 70-96 (80).

lxxxiv 'Accounts of the Dean of Guild', 78, 84 [9 Dec. 1608; 26 Dec. 1608; 20 Jan. 1609; 6 Apr. 1609].

lxxxv Glasgow Extracts, 344, 348 [1 Dec. 1624; 23 July 1625]; Edinburgh Extracts VI, 180-181, 231, 260 [19 Aug. 1618; 16 Sept. 1618; 3 May 1622; 15 Dec. 1624]; Maxwell, History of Dundee, 380-381; Stuart (ed.), 'Treasurer's Accounts', 138 [1608-09], 147 [Oct. 1629]; 'Accounts of the Dean of Guild', 87.

lxxxvi ACR, 52.265-266 [28 Apr. 1636]; ACR, 52.297 [28 Sept. 1636]; M. Wood (ed.), Extracts from the Records of the Burgh of Edinburgh, 1626-1641 [Edinburgh Extracts VII] (Edinburgh, 1936), 176, 177, 184, 196, 249 [30 Apr. 1636; 25 May 1636; 25 Nov. 1636; 6 Oct. 1637; 14 July 1641]; M. Wood (ed.), Extracts from the Records of the Burgh of Edinburgh, 16421655 [Edinburgh Extracts VIII] (Edinburgh, 1938), 31-32, 50, 5254 [16 Aug. 1643; 28 Aug. 1644; 18 Sept. 1644-25 Oct. 1644].

lxxxvii Stuart (ed.), 'Treasurer's Accounts', 150; L.B. Taylor (ed.), Aberdeen Council Letters, vol. 2: 1634-1644 (Oxford, 1950), 67. 
lxxxviii Examples of specific reference to the presence of plague within the city include: "this contageus pestilence ringand in ale partis about this burgh"; "the pest now ringand in the same [burgh]"; an acknowledgement of the presence of "seik folkis"; and the differentiation of "suspect personis of this pest" from the "haill [healthy] pepill" who comprised the majority of society. See ACR, 9.336 [24 Apr. 1514]; ACR, 19.018 [5 Feb. 1546]; ACR, 18.565 [20 Nov. 1545]; ACR, 18.541 [9 Oct. 1545]; ACR, 20.310 [16 Oct. 1549].

lxxxix ACR, 9.336 [24 Apr. 1514] - ACR, 9.584 [5 May 1516]; ACR, 18.527 [25 Sept. 1545] - ACR, 19.394 [19 Sept. 1547]; ACR, 20.310 [16 Oct. 1549] - ACR, 20.318 [8 Nov. 1549]; ACR, 53/2.1457 [27 Apr. 1647] -ACR, 53/1.304-05 [15 Dec. 1647].

xc Dennison, DesBrisay and Diack, 'Health in the Two Towns', 80.

xci As time passed without actual infection this recourse to past actions - the use of bureaucratic "memory" - proved all the more necessary. For more on memory, see A.G. Carmichael, 'The Last Past Plague: The Uses of Memory in Renaissance Epidemics', Journal of the History of Medicine and Allied Sciences 53 (1998), 132-160.

xcii Creighton, History of Epidemics in Britain, 371.

xciii "Plague policy in Scotland was strictly and brutally enforced." See N. Gallagher, 'Public Health and Social Medicine: The Historical Legacy of the English Plague Experience', University of Vermont History Review 6 (1994), n.40. See also, Shrewsbury, History of Bubonic Plague, 185-86; and the works on Scottish plague already cited.

xciv Tyson, 'People in the Two Towns', 113.

xcv ACR, 31.612-613 [21 May 1585]; ACR, 31.616 [27 May 1585]; ACR, 31.662 [23 Aug. 1585]; ACR, 31.666-667 [8 Sept. 1585]; ACR, 31.668 [18 Sept. 1585].

xcvi ACR, 43.765-766 [8 Nov. 1608]; 'Accounts of the Dean of Guild', 108-109. xcvii Edinburgh Extracts III, 416 [10 May 1585]. 